\title{
Participation of Women in the Economic Activity in Cameroon
}

\author{
Henri Bello Fikaa, Germain Dzoyem Sokenga
}

\begin{abstract}
The aim of this paper is to put forward the explanatory factors of the participation of women in the economic activity in the Cameroonian context characterized by an important and persistent gender gap in terms of participation in the economic activity (more men than women). The authors carried out, on the basis of data resulting from the DHS-MICS 2011, an analysis using the binomial logistic model. It comes out from this analysis that the significant explanatory variables are the age (which plays at the same time the role of variable of control), the religion, the ethnic group, the size of the household, the relationship with the head of household, the educational level (of the woman and the husband/partner), the occupational status of the husband/partner, the household's standard of living, and the marital status. According to the results obtained, it would be important to set up policies intended to reinforce the professionalization of the young woman and to fight against the sexist sociocultural norms and practices advocating the "sexual division" of labor.
\end{abstract}

\section{Keywords}

Economic activity, women, gender, development, logistic model

The economic, social, and political development of a country cannot be made without the effective participation of all the strata of society in particular women, whose demographic weight is not the least (Lopez-Claros and Zahidi 2005). Indeed, the rise of the female economic activity does not improve only the situation of the women, but also that of the society as a whole by stimulating the economic growth, by balancing the retirement system and by reducing the families' risk of poverty (Letablier et al. 2009; Galor and Weil 1996; Desvaux, Devillard, and Baumgarten 2007). The participation of the women in the economic activity thus constitutes a powerful factor of improvement of the economic performances of a country (Klasen 1999; Pissarides 2006). These facts thus call into question the traditional model of the man provider and the woman devoted to the domestic businesses, i.e., a system characterized by the association of the active and productive pole to the men and of the passive and reproductive axis to the women. Besides, this justifies the fifth Objectives of the Durable Development (ODD). Thus, the question of the importance of the female human capital for the economic development challenges the industrialized economies as well as developing ones and thus, a fortiori the countries of Sub-Saharan Africa among which Cameroon, space chosen for our study.

According to data provided by the World Bank (World Bank 2012), within the Cameroonian female population aged 15 years old and more, the

anstitute of Demographic Training and Research (IFORD), Cameroon

Correspondent Author:

Henri Bello Fika, IFORD, P.O. Box 1556, Yaounde, Cameroon 
participation rate in the economic activity knew only a very weak rise during the two last decades. Indeed, it passed from $55.3 \%$ in 1990 to approximately $64 \%$ in 2010 , that is to say, a rise of 8.6 percentage points. One observes moreover over the same period, a relatively weak rise of the female/male ratio in the rate of participation in the economic activity (going from $69.4 \%$ in 1990 to $82.7 \%$ in 2010 , that is to say, a rise of approximately 13.3 percentage points). This difference between men and women is also observed in the report of ECAM 3. In addition, according to data coming from DHS-MICS (Demographic and Health Survey-Multiple Indicators Clusters Survey) realized in Cameroon in 2011, the occupation rate ${ }^{1}$ is $68.1 \%$ among women whereas it is $87.2 \%$ among the men, that is to say, a significant gap of 19.1 percentage points. Thus, in terms of probability, the men have $28 \%$ more chances than the women to carry on an economic activity. Let us note in addition that this gap increased by 2004 to 2011 in the sense that in 2004, it was about $18 \%$. This "insufficient" participation of the women constitutes a proof of an underutilization of the economic potential in terms of human resources or of human capital that Cameroon could fully draw in order to accelerate its accession process to the status of emergent country. Hence, the interrogation that these empirical observations bring about is as follows: Why is this "timid" evolution of the participation of the female strata in the economic activity in Cameroun? This central question and the considerations mentioned above constitute the cogency of the authors' study. In this paper, they propose:

(1) To analyze the impact of the economic, sociodemographic, and sociocultural variables on the participation of women in the economic activity in the Cameroonian context;

(2) To determine the mechanisms of actions of the explanatory variables on the female participation in the economic activity in the Cameroonian context.

\section{LITERATURE REVIEW}

\section{The Neoclassical Theory}

According to the neoclassical theory, based on the assumption of the rational economic agent (homo oeconomicus), the labor market is based mainly on the economic motivation of the actors, i.e., on the research of the maximum satisfaction. If the employers seek an effective production at the lower cost, the workers, as for them, invest in education, training, and information with an aim of obtaining the best wages in the best working conditions.

According to Mincer (1962), the individual time allocation between work and leisure is a function of the wages. A rise in the labor remuneration has two effects: the income effect and the price effect or substitution effect.

The economic agent decides to work only if the income it obtains from this work is higher than the out-of-activity income; this income coming from work depends upon age and human capital (health and education). This aspect finds all its relevance more especially as if the wages of the spouse (of which one of the factors is the employment status) are high so that the woman's "reserve" wages are higher than that she would have obtained in the event of labor force participation, then she would not choose to work.

\section{The Survival Strategies Theory}

In order to analyze the links between poverty and labor market, it is advisable to apprehend each individual labor offer not like an isolated decision made according to its own characteristics but like dependent on the strategy of a broader group: household. According to the classical theory of the family economy (Becker 1981), each household maximizes her utility by allocating the total time available of each one of its members between commercial work and the production of the domestic goods. This allocation takes into consideration the 
heterogeneity of the roles and functions of the various household members. This distribution of roles which corresponds to the beckerian optimum must rather be perceived like a reference state, likely to vary according to the constraints and shocks to which the household faces.

\section{The Education Level}

The human capital endowment constitutes the principal determinant of salary, which is itself the principal determinant of the labor force participation. The individuals invest in themselves to profit from future monetary and nonmonetary outputs (Becker 1993). The human capital theory rejects the standard approach's homogeneity assumption of the labor as input by regarding the levels of qualification of the individuals as source of heterogeneity. Accordingly, Mincer (1974) derived an econometric model of profits in which the years of studies and the years of work respectively give an account of the accumulated human capital in initial formation and of the experiment of the individual. Kozel and Alderman (1990), Garcia (1995), Caputo (1997), Aly and Quisi (1996), Azid, Aslam, and Chaudary (2001), Hafeez and Ahmad (2002), and Naqvi and Shahnaz (2002) showed that the level of education has a positive and significant impact on the participation in the economic activity. In Nigeria, Aminu (2010) used the probit and multinomial methods by taking as a starting point the Mincerian model of the human capital. The analyses carried out on each of the two data bases of which it makes use reveal the positive influence of the educational level. Aromolaran (2004), in an empirical study carried out, always in Nigeria, shows that the participation of the women in the economic activity is positively influenced not only by their educational level, but also that of husband or partner (for the women living in union). This relation is confirmed by a study carried out in Ghana by Sackey (2005).

\section{Socio-Cultural Norms}

They pose the male domination as historical postulate. The inequalities which exist between the women and men in the labor market are only cases of discrimination resulting from the subordinate position of the woman in the society, position historically and culturally built (Locoh, Labourie-Racape, and Tichit 1996). The consequences of this subordination and the sexual division of the work which results from this make the women assume only the domestic work of production (children rearing, household production, etc.), have less time to take part in other types of activities, in fact economic (Hartmann 1976; Sacks 1979; Dussault 1987). Chamlou, Muzi, and Ahmed (2011) noted, in a study undertaken in the countries of the Middle-East and North Africa (MENA), a high level of education in this area, accompanied however by a relatively weak female participation in paid work, which leads them to analyze the role of the social norms in the participation of women in the economic activity. The results they obtain show that the rate of female participation of the migrants in paid work reflects on the whole that their countries of origin and that the traditional social norms constitute an obstacle to this participation.

Farre and Vella (2007) were further showing that the conservative attitude of the woman significantly influences the perception of her children regarding the participation of the woman in the economic activity, influencing significantly the decision of her daughters and daughters-in-law to fit on the labor market. Fernandez, Fogli, and Olivetti (2004) fell under the same order of idea by specifying that having a husband whose mother works or worked, increases significantly the probability for a married woman to work full-time and this, beyond the considerations of the other variables.

According to Fraser (1990), there is possible interdependence between conservative social norms and female labor; hence there is an eventual problem 
of endogeneity. This idea is shared by Seguino (2007) with the only difference that for the latter, the work of the woman has also an influence on the attitudes of the latter, but with certain shift in time.

\section{Marital Status}

Several authors such as Naqvi and Shahnaz (2002) and Chaudhry and Nasheen (2009) established a relationship between participation of the woman in the economic activity and marital status. But regarding the various results of the empirical studies, we can say that the marital status presents an ambivalent effect. Indeed, for Longwe, Smits, and Jong (2013) and Angrist (2001), the married women have less chances than the single, divorced, separated, and the widowed ones to fit on the labor market. They thus join Benefo and Pillai (2003), Ntuli and Wittenberg (2013), Shaheen, Maqbool, and Masood (2011) and Contreras and Plaza (2010).

Naqvi and Shahnaz (2002) obtained opposite results to those mentioned above, with the only difference that they restrict their sample to the unmarried women and those in union. According to these authors indeed, women in union have more chance to fit on the labor market than those who are unmarried.

Fadayomi and Ogunrinola (2014) as for them, carried out a thorough analysis by showing that divorced and the separate ones fit more easily on the labor market than the married women who, fit more easily than the unmarried women.

\section{Number of Children}

Azid et al. (2001) and Naqvi and Shahnaz (2002) showed that the number of children has a positive influence on the participation of the women in the economic activity. This result is conform to the model of the survival strategy mentioned above. But it is not shared by authors like Chaudhry and Nasheen (2009), Contreras and Plaza (2010), Naqvi and Shahnaz (2002), Contreras, Puentes, and Bravo (2005), Garcia
(1995) and Caputo (1997). These authors show that the participation of the women in the economic activity is influenced negatively and significantly by the number of children. One can however note that these authors do not mention the children age; this constitutes certainly the source of the divergence between these results insofar as the more the children grow, the higher the financial expenses are, which encourages the woman to be invested on the labor market, or to increase her work offer for an additional income. A contrario seu, the younger the child is, the more the woman is forced to reduce, or even suspend her work to take care of the latter.

Longwe et al. carried out into 2013 empirical work consisting in analyzing the effect of the parity and spacing between the last two (2) children on the insertion of the woman on the nonagricultural labor market in Africa. The data they exploit relate to more than 200,000 women having at least a child in a sample made up of 26 African countries. After having dealt with problem of endogeneity between fertility and the participation of the women with the economic activity, they show that the latter is negatively correlated with the number of recent births (children of less than five years) and positively correlated with the spacing of the recent births. By analyzing the interactions, they show that these effects are more significant among women having a higher educational level and those living in urban zone. In addition, these effects become weak with family planning.

\section{Age}

Many authors agree with the fact that the woman's age positively influences her participation in the economic activity. We can quote for example Azid et al. (2001), Naqvi and Shahnaz (2002), Aminu (2010), Faridi, Chaudhry, and Anwar (2009), Garcia (1995) and Caputo (1997). Contreras and Plaza (2010) were further showing that this positive effect decreases with the age (concavity). Fadayomi and Ogunrinola (2014) went in the same direction by showing as the probability 


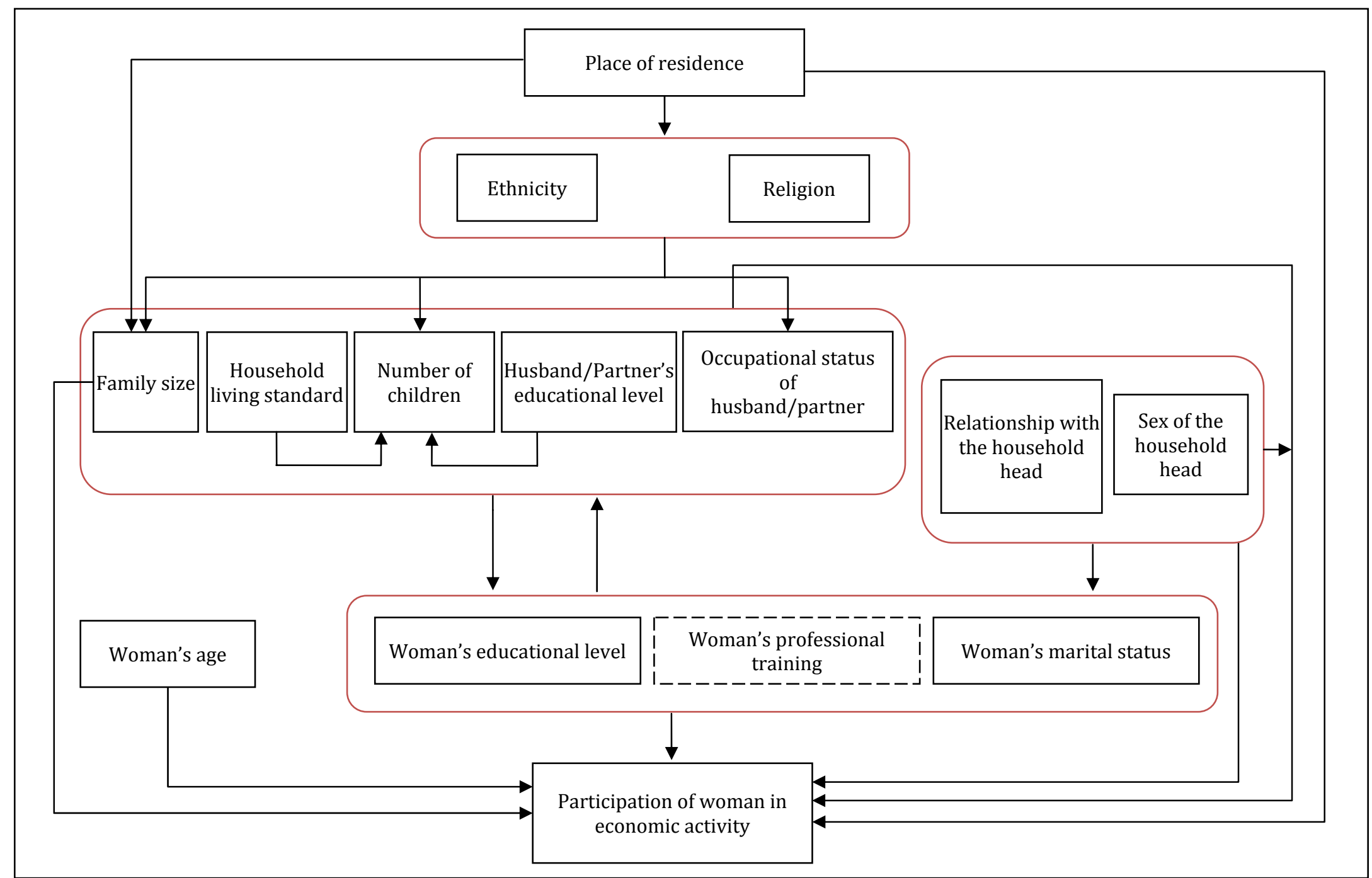

Figure 1. The Analysis Scheme.

Note: Source: The authors. 
for a woman to obtain a paid employment increases with the age, up to 64 years old. For Contreras et al. (2005), the effect of the age follows a concave evolution and reaches the maximum effect at 36 years. Indeed, the younger the troop is, the more the chance of participating in the economic activity increases.

The synthesis of all the analyses presented above permitted us to elaborate the analysis diagram dipicted in Figure 1.

\section{METHODOLOGY}

\section{Sample and Source of Data}

The data used are those of DHS-MICS 2011 which made it possible to collect data such as socio-economic, demographic, and sociocultural data of the women between 15 and 49 years old as well as the data relating to housing. These data were collected on 14,214 households and 15,246 women.

\section{Evaluation of the Data Quality: Births of the Five Years Preceding the Survey}

Graphic evaluation. The curve presented in Figure 2 has a normal shape; this could lead us to think that the quality of data on births of the five years preceding the survey is good. But to confirm it, it could be important to complete this graphic evaluation by a statistical one. We choose for this purpose the method of Brass and Rachad.

Statistical evaluation: Brass \& Rachad method. According to the method of Brass and Rachad (See Handbook $X$ of United Nations 1984), if $\operatorname{Min}(A, B)$ is higher than the parity observed corresponding to the old women of 45 to 49 years old (P7), then there are under declaration (or omission) of births. The values of $\mathrm{A}$ and $\mathrm{B}$ are given by the following formulas:

$$
\left\{\begin{array}{c}
A=\frac{\left(P_{3}\right)^{2}}{P_{2}} \\
B=P_{2} *\left(\frac{P_{4}}{P_{3}}\right)^{4}
\end{array}\right.
$$

A and B can be obtained by using the estimated parities using the method of Brass (see Appendix 1).

$$
\left\{\begin{array}{c}
A=\frac{\left(F_{3}\right)^{2}}{F_{2}} \\
B=F_{2} *\left(\frac{F_{4}}{F_{3}}\right)^{4}
\end{array}\right.
$$

Calculations carried out reveal that $\operatorname{Min}(A, B)=$ $4,855,199<F 7=5,063,114$ (see Appendix 1). The data are thus of good quality.

\section{Variables}

The dependent variable. The aim of our study is to determine the factors which are likely to influence the participation of the women in the economic activity, our dependent variable is the exercise of the economic activity during the 12 months preceding the survey. It is a dichotomic variable whose values are:

$$
Y=\left\{\begin{array}{c}
1 \text { ifthe woman has exerted an economic } \\
\text { activity during the last } 12 \text { months } \\
0 \text { if not }
\end{array}\right.
$$

The independent variables. The independent variables are presented varibles and their modalities are presented in Table 1.

\section{The Binomial Logistic Model}

Why is the binomial logistic model suitable for our analysis? Let us consider the following model:

$$
Y=\alpha+\sum_{i=1}^{n} \beta_{i} * X_{i}+\mu_{i}
$$

This equation can also be rewritten as follows:

$$
Y=\beta * X+\mu_{i}
$$

Where

$$
\beta=\left(\alpha, \beta_{1}, \beta_{2}, \ldots, \beta_{i}, \ldots, \beta_{n}\right)
$$

et

$$
X={ }^{t}\left(1, X_{1} X_{2}, \ldots, X_{i}, \ldots, X_{n}\right)
$$

with:

$$
\left\{\begin{array}{c}
\alpha=\text { scalar representing the constant term } \\
\beta_{i}=\text { multiplicative parameter of the } i^{t h} \\
\text { independant variable } \\
\mu_{i}=\text { error term }
\end{array}\right.
$$


Table 1. Independent Variables

\begin{tabular}{|c|c|}
\hline Variables & Modalities \\
\hline Place of residence & Large city; Small city; Rural \\
\hline Religion & Catholic; Protestant; Muslim; Animist; Other Christian; No religion \\
\hline Ethnicity & $\begin{array}{l}\text { Arab-Choa/Peulh/Haoussa/Kanuri; Biu-Mandara; } \\
\text { Adamaoua-Oubangui; Bantoïde Sud-Ouest; Grassfields; Bamiléké; } \\
\text { Côtier/Ngoe/Oroko; Beti/Bassa/Mbam; Kaka/Maka/Pygmée }\end{array}$ \\
\hline Educational level & No education; Primary; Secondary; Higher \\
\hline Husband/Partner's eductional level & No education; Primary; Secondary; Higher \\
\hline Type of husband/partner's occupation & $\begin{array}{l}\text { Not working; Manag./tech.; Clerical; Sales; Domestic; } \\
\text { Services; Skilled manual; Unskilled manual; Agriculture }\end{array}$ \\
\hline \multicolumn{2}{|l|}{ Household size } \\
\hline \multicolumn{2}{|c|}{ Number of children under 5 years old (De jure) } \\
\hline Marital status & Single; In union; Widowed; Divorced/Separated \\
\hline Sex of household head & Male; Female \\
\hline Relationship with the household head & $\begin{array}{l}\text { Head; Wife; Daughter; Daughter-in-law; Granddaughter; } \\
\text { Mother/Mother-in-law/Sister; Other relationship; Adoptive } \\
\text { daughter; Not related; Niece }\end{array}$ \\
\hline Standard of living & Lowest; Low; Medium; Hight; Highest \\
\hline \multicolumn{2}{|c|}{ Number of births of the 5 years preceding the survey } \\
\hline Ages group & Quinquennial ages groups \\
\hline
\end{tabular}

Note: The respective rates of non-response of the variables mentioned above are all lower than $10 \%$, conventional level retained by the United Nations.

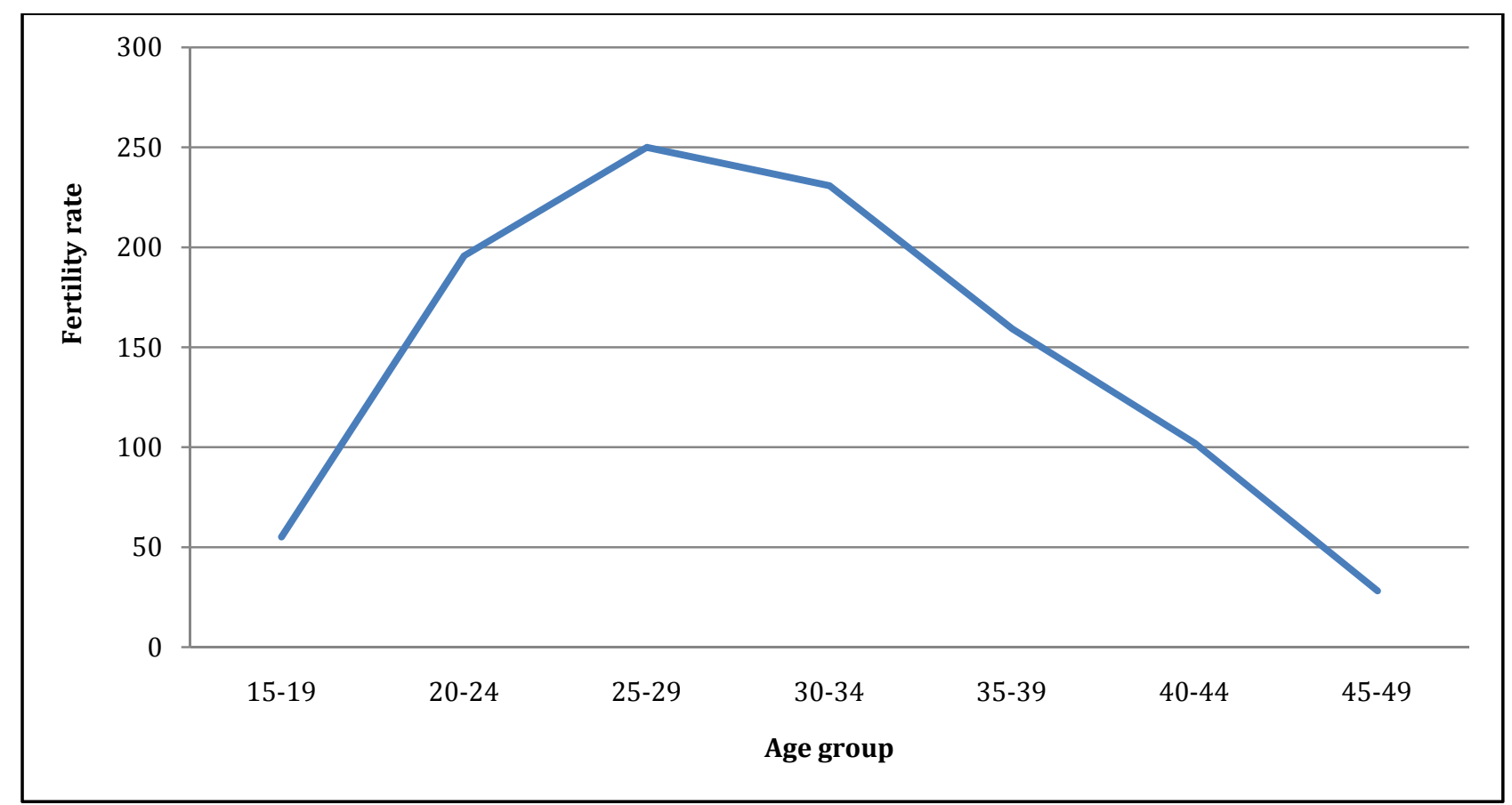

Figure 2. The Evolution of the Fertility Rate of by Age Group for the Five Last Years.

Note: Source: Exploitation of DHS-MICS Data (2011). 
Let us consider the following model: $\widehat{Y}=\hat{\beta} * X$

If $\hat{Y}$ is a dichotomic variable taking values 0 et 1 , then we will have:

$$
\begin{aligned}
& \text { For } \hat{Y}=1: \widehat{\mu}=1-\hat{\beta} * X \\
& \quad \text { For } \hat{Y}=0: \widehat{\mu}=\hat{\beta} * X
\end{aligned}
$$

Because $Y$ takes only two values, the error term can also take only two values. The checking of one of the assumptions thus poses problem; that is the assumption of homoscedasticity. Indeed, the variance of these errors depends on $X$. It is thus not constant.

The linear model (term of right-hand side) can lead to values apart from those of the interval and that even though the values of $X$ are reasonable. This supposes that we estimate parameters which do not exist. A way of regulating this problem is to find functions which avoid falling apart from the interval $(0,1)$. The logit model is one of these functions.

Presentation of the binomial logistic model. Let $\operatorname{Prob}(Y=1)$ and $\operatorname{Prob}(Y=0)$ be the respective probabilities that $Y$ equals respectively 1 and 0 .

$$
\begin{gathered}
\operatorname{Prob}(Y=1)=\frac{e^{\beta * X}}{1+e^{\beta * X}}=F(\beta * X) \\
\operatorname{Prob}(Y=0)=1-F(\beta * X)
\end{gathered}
$$

Where, $F$ represents the cumulative distribution logistic function.

$$
\begin{gathered}
E[Y / X]=0[1-F(\beta * X]+1[F(\beta * X)]= \\
{[F(\beta * X)]}
\end{gathered}
$$

By setting $z=\beta^{*} X$, we obtain:

$$
\begin{gathered}
\operatorname{Prob}(Y=1)=\frac{e^{z}}{1+e^{z}}=\Pi_{i} \\
\Rightarrow \log \left(\frac{\Pi_{i}}{1-\Pi_{i}}\right)=\beta^{*} \mathrm{X} \\
\Rightarrow \operatorname{logit}\left(\Pi_{i}\right)=\beta^{*} \mathrm{X}
\end{gathered}
$$

Let us also set:

$$
\begin{gathered}
\Pi_{1}=\operatorname{Prob}\left(Y=1 \mid x_{i}=1\right)=\frac{e^{\alpha+\beta_{i}}}{1+e^{\alpha+\beta_{i}}} \\
1-\Pi_{1}=\operatorname{Prob}(Y=0 \mid x=1)=\frac{1}{1+e^{\alpha+\beta_{i}}}
\end{gathered}
$$

$$
\begin{gathered}
\Pi_{0}=\operatorname{Prob}(Y=1 \mid x=0)=\frac{e^{\alpha}}{1+e^{\alpha}} \\
1-\Pi_{0}=\operatorname{Prob}(Y=0 \mid x=0)=\frac{1}{1+e^{\alpha}}
\end{gathered}
$$

We thus obtain the following expression:

$$
O R=\left(\frac{\Pi_{1}}{1-\Pi_{1}}\right) /\left(\frac{\Pi_{0}}{1-\Pi_{0}}\right)=e^{\beta_{i}}
$$

$O R=$ odds ratio or ratio of chances. An $O R>1$ indicates that variable $x_{i}$ has a positive effect on the probability of realization of the event " $Y=1$ " (for our analysis, this event is the participation in an economic activity). A contrario seu, an $O R<1$ means that variable $x_{i}$ decreases the probability of realization of the event $Y=1$.

The coefficients $\beta_{i}$ are estimated by the method of the maximum likelihood. Taking into account the nonlinearity of the model, these parameters are estimated by iteration.

Generally, we have:

$$
\frac{\delta \log (\text { odds ratio })}{\delta x_{i}}=\beta_{i}
$$

$\beta_{i}$ represents the Napierian logarithm of the odds-ratio associated with one unit increase of the explanatory variable $x_{i}$.

For the continuous explanatory variables, it is possible to calculate the variation of probability when the variable $X_{i}$ grows by a unit. This variation can be calculated by using the following expression:

$$
\frac{\delta \Pi_{i}}{\delta x_{i}}=\frac{\beta_{i} * e^{-z}}{\left[1+e^{-z}\right]^{2}}
$$

\section{Softwares Use}

The softwares chosen for our analysis are Stata/SE 12 and Spss-IBM 20 because of their complementarity. We use also Excel (Office 2010) for additional calculations, the generation of graphs and the elaboration of tables. 


\section{RESULTS}

\section{Results of the Tests of the Model's Robustness}

The probability associated with the statistics of khi-square shows that the estimated model is overall significant at $1 \%$ level. The goodness of fit test shows us that the model is adjusted at $79.38 \%$ (see Table 2). This satisfactory adjustment quality is also shown at the end of the test of Hosmer-Lemeshow. The calculated value of the ROC (Receiver Operating Characteristic) is about .7635 (See Figure 3), which is satisfactory from the point of view of the degree of discrimination. We can consequently consider the results obtained from the estimates of our model parameters.

\section{Results of the Estimation of the Model's Parameters}

The results reveal that among the explanatory variables, the non-significant ones at the 5\% level of signification are: sex of the head of household, number of children of less five (5) years living in the household, and the number of births of five (5) last years preceding the survey. The results also show that:

(1) The chances of the woman to carry on an economic activity increase with its age, but at a decreasing rate, which is up to our expectations;

(2) The women of primary educational level have 1.3 times more chances to participate in an economic activity than those of secondary level; the modalities "no education" and "higher" do not have a significant effect on the probability of participating in an economic activity;

(3) The Muslim women have .65 times less chances to carry on an economic activity than those of Catholic religion;

(4) The women of ethnic group Arab-Choa/Peulh/Houssa/Kanuri and those of the grassfields have respectively .45 times less chances and 2.11 times more chances to carry on an economic activity than those of Bamiléké/Bamoun group;

(5) The women living in the households made up of 11 to 15 members have .82 times less chances to participate in an economic activity than those living in the households comprising 6 to 10 members;

(6) The women residing in the large/small cities have .6 times less chances to carry on an economic activity than those living in rural zone;

(7) The women who are heads of household have 1.71 times more chances to participate in economic activity than those which are wives of heads of household;

(8) The women of low or average standard of living have on average 1.6 times more chances to carry on an economic activity than those of high standard of living;

(9) The divorced/separated women have 1.5 times more chances to carry on an economic activity than those living in union;

(10) The women whose husband/partner has a primary educational level have .7 times less chances to participate in an economic activity than those whose husband/partner has a secondary level;

(11) The women whose husband/partner does not work have .46 times less chances to carry on an economic activity than those whose husband/partner is working in agricultural sector.

\section{Hierarchical Organization of Variables}

Table 3 emphasized the hierarchy of the explanatory variables according to their respective contribution to the explanation of the studied phenomenon.

\section{Mechanisms of Action of the Independent Variables on Female Participation in Economic Activity (See Appendix 2)}

The inclusion of the variable "Religion" (model M2) annuls the significance of the "south-western" modality of the Ethnicity variable at $10 \%$ level of signification. This is the proof that the ethnic group affects the participation of women in the economic activity via the religion. The inclusion of the variable "Educational level of the spouse" (model M4) annuls the significance 


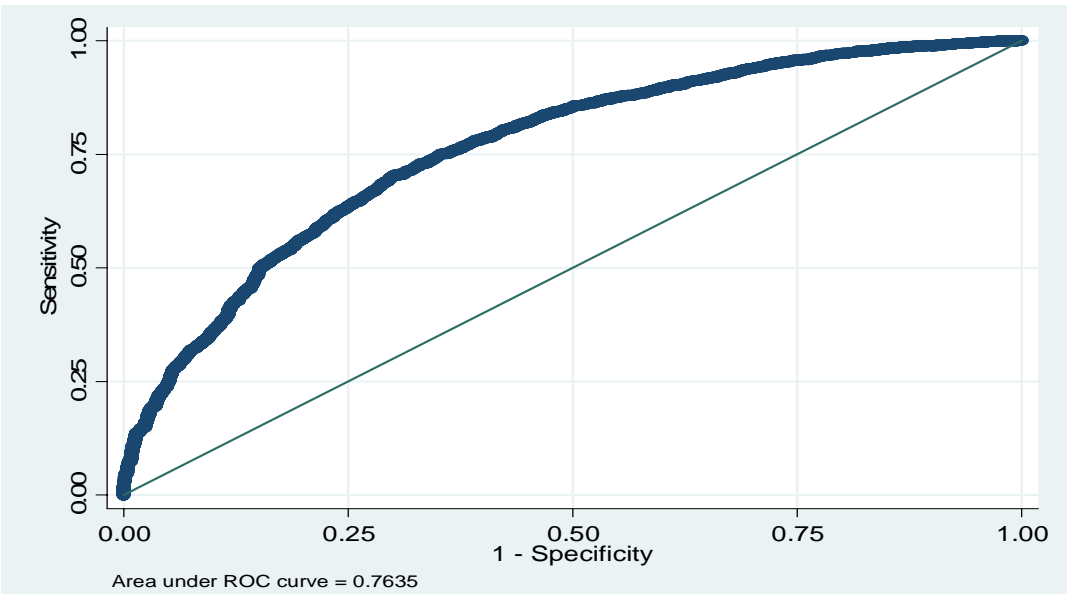

Figure 3. The ROC (receiver operating characteristic) curve.

Note: Source: Exploitation of DHS-MICS Data (2011).

Table 2. Classification Matrix

\begin{tabular}{|c|c|c|c|}
\hline & True & & \\
\hline Classified & $\mathrm{D}$ & $\sim \mathrm{D}$ & Total \\
\hline+ & 7,079 & 1,635 & 8,714 \\
\hline- & 364 & 617 & 981 \\
\hline Total & 7,443 & 2,252 & 9,695 \\
\hline \multicolumn{4}{|c|}{$\begin{array}{l}\text { Classified }+ \text { if predicted } \operatorname{Pr}(D) \geq .5 \\
\text { True D defined as } V 731 \neq 0\end{array}$} \\
\hline Sensitivity & & $\operatorname{Pr}(+\mid \quad D)$ & $95.11 \%$ \\
\hline Specificity & & $\operatorname{Pr}(-\mid \sim D)$ & $27.40 \%$ \\
\hline Positive predictive value & & $\operatorname{Pr}(\mathrm{D} \mid+)$ & $81.24 \%$ \\
\hline Negative predictive value & & $\operatorname{Pr}(\sim \mathrm{D} \mid-)$ & $62.90 \%$ \\
\hline False + rate for true $\sim D$ & & $\operatorname{Pr}(+\mid \sim D)$ & $72.60 \%$ \\
\hline False - rate for true $\quad D$ & & $\operatorname{Pr}(-1 \quad D)$ & $4.89 \%$ \\
\hline False + rate for Classified + & & $\operatorname{Pr}(\sim \mathrm{D} \mid+)$ & $18.76 \%$ \\
\hline False - rate for Classified - & & $\operatorname{Pr}(\mathrm{D} \mid-)$ & $37.10 \%$ \\
\hline Correctly classified & & & $79.38 \%$ \\
\hline
\end{tabular}

Note: Source: Exploitation of DHS-MICS Data (2011).

of the modality "Biu-Mandara" of the ethnicity and decreases that of the modality "11-15" of the household size. The educational level of the spouse thus constitutes a partial intermediate variable by which the ethnic group and the size of the household influence the participation of the woman in the economic activity. Furthermore, the type of occupation of the spouse constitutes, on the one hand, a variable by which the educational level of the spouse acts, and on the other hand, an inhibiting variable of the ethnic group (model M5). Let us note in addition that the standard of living of the household is a partial inhibiting variable of the ethnos group and an intermediate variable of the educational level and type of occupation of the spouse (model M6). Moreover, the relationship with the head of household and the 
Table 3. Contribution of Explanatory Variables

\begin{tabular}{llllll}
\hline Variables & $\chi_{i}^{2}$ & $\chi_{f}^{2}$ & $\left(\chi_{f}^{2}-\chi_{i}^{2}\right) / \chi_{f}^{2}$ & $\begin{array}{l}\text { Contribution } \\
(\%)\end{array}$ & Rank \\
\hline Ages group & $1,282.20$ & $1,639.47$ & .217918 & 21.7918 & 1 \\
Place of residence & $1,604.49$ & $1,639.47$ & .021336 & 2.133616 & 5 \\
Ethnicity & $1,527.14$ & $1,639.47$ & .068516 & 6.851604 & 2 \\
Religion & $1,596.09$ & $1,639.47$ & .02646 & 2.645977 & 4 \\
Household size & $1,633.47$ & $1,639.47$ & .00366 & .365972 & 12 \\
Husband/Partner's eductional level & $1,620.05$ & $1,639.47$ & .011845 & 1.184529 & 9 \\
Type of Husband/Partner's occupation & $1,590.75$ & $1,639.47$ & .029717 & 2.971692 & 3 \\
Living standard & $1,617.05$ & $1,639.47$ & .013675 & 1.367515 & 8 \\
Relationship with the household head & $1,606.02$ & $1,639.47$ & .020403 & 2.040294 & 6 \\
Sex of household head & $1,635.72$ & $1,639.47$ & .002287 & .228732 & 13 \\
Numbers of children under 5 years old (De jure) & $1,632.73$ & $1,639.47$ & .004111 & .411108 & 11 \\
Marital status & $1,629.41$ & $1,639.47$ & .006136 & .613613 & 10 \\
Educational level & $1,609.97$ & $1,639.47$ & .017994 & 1.799362 & 7 \\
Number of births of the 5 years preceding the survey & $1,638.38$ & $1,639.47$ & .000665 & .066485 & 14 \\
\hline
\end{tabular}

Note: Source: Exploitation of DHS-MICS Data (2011).

sex of the head of household are respectively partial inhibiting variables of occupation status of the spouse and religion (models M8 and M9). The inclusion of the variable "Numbers children of less than five (5) years" (model M10) reduces the significance of the "Protestant" modality of the religion. This last influences thus the participation of the woman in the economic activity via the number of children of less than five years old living in the household. The inclusion of the woman's educational level (model M11) shows that it is a partial intermediate variable of the ethnic group, religion, household size, woman's educational level and household's living standard. Finally, in the last model (model M12), one notices that the religion, the size of the household, and the sex of the head of household act via the marital status.

\section{CONCLUSIONS}

The principal aim of this paper was to determine the explanatory factors of the participation of women in the Cameroonian context. To arrive there, the authors carried out a short review of the literature which leads them to the elaboration of an analysis diagram. They then examined the rates of non-response and the quality of the data on births of the five years preceding the DHS-MICS survey. The authors thereafter presented the model used for their analysis (binomial logistic model). It comes out from their analysis that the significant explanatory variables are the age group, which plays at the same time the role of control variable, the religion, the ethnos group, the size of the household, the relationship with the head of household, the educational level (of the woman and of the husband/partner), the husband/partner's occupational status, the household standard of living, and the marital status. According to the results obtained, it would be important to set up policies intended to reinforce the professionalization of the young woman and to fight against the sexist values that advocate the sexual division of labor. 


\section{Appendix}

Appendix 1. Results of the Calculation of the Estimated Parity by the Brass's Method

\begin{tabular}{|c|c|c|c|c|c|c|c|c|c|c|}
\hline $\mathrm{i}$ & Groups of age & $\begin{array}{l}\text { Number of } \\
\text { women }\end{array}$ & $\begin{array}{l}\text { Births of five } \\
\text { recent years }\end{array}$ & $\begin{array}{l}\text { Average annual } \\
\text { births }\end{array}$ & Fertility rate & Cumulation & $\mathrm{a}$ & $\mathrm{b}$ & c & $\mathrm{Fi}$ \\
\hline 1 & $15-19$ & 3,590 & 990 & 198 & 55.1532 & 275.766 & 2.147 & -.244 & .0034 & 88.00754 \\
\hline 2 & $20-24$ & 3,118 & 3,052 & 610.4 & 195.7665 & $1,254.599$ & 2.838 & -.758 & .0162 & 724.527 \\
\hline 3 & $25-29$ & 2,661 & 3,327 & 665.4 & 250.0564 & $2,504.88$ & 2.76 & -.594 & .0133 & $1,875.559$ \\
\hline 4 & $30-34$ & 1,908 & 2,202 & 440.4 & 230.8176 & $3,658.969$ & 2.949 & -.566 & .0025 & $3,108.196$ \\
\hline 5 & $35-39$ & 1,688 & 1,344 & 268.8 & 159.2417 & $4,455.177$ & 3.029 & -.823 & .0006 & $4,060.396$ \\
\hline 6 & $40-44$ & 1,274 & 650 & 130 & 102.0408 & $4,965.381$ & 3.419 & -.966 & -.0001 & $4,720.086$ \\
\hline \multirow[t]{2}{*}{7} & $45-49$ & 1,187 & 167 & 33.4 & 28.13816 & $5,106.072$ & 3.535 & -.007 & -.0002 & $5,063.114$ \\
\hline & Total & 15,426 & 11,732 & $2,346.4$ & & & & & & \\
\hline
\end{tabular}

$A=4,855.199$

$B=5,464.683$

Note: Source: Exploitation of DHS-MICS Data (2011). 
Appendix 2. Increasing Step Model

\begin{tabular}{|c|c|c|c|c|c|c|c|c|c|c|c|c|c|c|}
\hline \multirow{2}{*}{$\begin{array}{l}\text { Variables and } \\
\text { modalities }\end{array}$} & \multirow{2}{*}{$\begin{array}{l}\text { Gross } \\
\text { effects }\end{array}$} & \multicolumn{13}{|c|}{ Net effects } \\
\hline & & M0 & M1 & M2 & M3 & M4 & M5 & M6 & M7 & M8 & M9 & M10 & M11 & M12 \\
\hline \multicolumn{2}{|c|}{$\begin{array}{l}\text { Place of residence }(\mathrm{ref}= \\
\text { rural) }\end{array}$} & $* * *$ & $* * *$ & $* * *$ & $* * *$ & $* * *$ & $* * *$ & $* * *$ & $* * *$ & $* * *$ & $* * *$ & $* * *$ & $* * *$ & $* * *$ \\
\hline Largecity & $.601^{* * *}$ & $.552^{* * *}$ & $.419 * * *$ & $.403^{* * *}$ & $.390^{* * *}$ & $.408^{* * *}$ & $.462^{* * *}$ & $.610^{* * *}$ & $.601^{* * *}$ & $.605^{* * *}$ & $.602^{* * *}$ & $.602^{* * *}$ & $.614^{* * *}$ & $.601^{* * *}$ \\
\hline Smallcity & $.585^{* * *}$ & $.535^{* * *}$ & $.477^{* * *}$ & $.475^{* * *}$ & $.474^{* * *}$ & $.469^{* * *}$ & $.526^{* * *}$ & $.617^{* * *}$ & $.602^{* * *}$ & $.605^{* * *}$ & $.606^{* * *}$ & $.603^{* * *}$ & $.603^{* * *}$ & $.600^{* * *}$ \\
\hline \multicolumn{2}{|c|}{$\begin{array}{l}\text { Ethnicity (ref = } \\
\text { bamiléké/bamoun) }\end{array}$} & & $* * *$ & $* * *$ & $* * *$ & $* * *$ & $* * *$ & $* * *$ & $* * *$ & $* * *$ & $* * *$ & $* * *$ & $* * *$ & $* * *$ \\
\hline Ar/peuhl & $.304^{* * *}$ & & $.246^{* * *}$ & $.351^{* * *}$ & $.349^{* * *}$ & $.412^{* * *}$ & $.422^{* * *}$ & $.417^{* * *}$ & $.420^{* * *}$ & $.418^{* * *}$ & $.417^{* * *}$ & $.417^{* * *}$ & $.449^{* * *}$ & $.445^{* * *}$ \\
\hline Biu-mand & $.952(\mathrm{~ns})$ & & $.730^{* * *}$ & $.758^{* * *}$ & $.766^{* * *}$ & $.857(\mathrm{~ns})$ & $.853(\mathrm{~ns})$ & $.806^{* *}$ & $.804^{* *}$ & $.860^{* *}$ & $.792^{* *}$ & $.789 * *$ & $.826^{*}$ & $.817^{*}$ \\
\hline Adm-oub & $1.197^{*}$ & & $.888(\mathrm{~ns})$ & $.898(\mathrm{~ns})$ & $.912(\mathrm{~ns})$ & $.964(\mathrm{~ns})$ & $.937(\mathrm{~ns})$ & $.906(\mathrm{~ns})$ & $.893(\mathrm{~ns})$ & $.894(\mathrm{~ns})$ & $.887(\mathrm{~ns})$ & $.884(\mathrm{~ns})$ & $.885(\mathrm{~ns})$ & $.874(\mathrm{~ns})$ \\
\hline Sth-west & $2.196^{* * *}$ & & $1.768^{* *}$ & $1.573(\mathrm{~ns})$ & $1.561(\mathrm{~ns})$ & $1.611(\mathrm{~ns})$ & $1.658^{*}$ & $1.670^{*}$ & $1.649^{*}$ & $1.665^{*}$ & $1.665^{*}$ & $1.666^{*}$ & $1.630(\mathrm{~ns})$ & $1.603(\mathrm{~ns})$ \\
\hline Grssfields & $3.302^{* * *}$ & & $2.606^{* * *}$ & $2.306^{* * *}$ & $2.255^{* * *}$ & $2.182^{* * *}$ & $2.186^{* * *}$ & $2.222^{* * *}$ & $2.213^{* * *}$ & $2.217^{* * *}$ & $2.189 * * *$ & $2.188^{* * *}$ & $2.113^{* * *}$ & $2.109^{* * *}$ \\
\hline Côtier/... & $1.527^{* * *}$ & & 1.249 (ns) & $1.098(\mathrm{~ns})$ & $1.099(\mathrm{~ns})$ & $1.139(\mathrm{~ns})$ & $1.126(\mathrm{~ns})$ & $1.152(\mathrm{~ns})$ & $1.162(\mathrm{~ns})$ & $1.160(\mathrm{~ns})$ & 1.149 (ns) & $1.153(\mathrm{~ns})$ & $1.152(\mathrm{~ns})$ & 1.145 (ns) \\
\hline $\mathrm{Bti} / \mathrm{bsa} / \mathrm{mbm}$ & $1.028(\mathrm{~ns})$ & & $1.004(\mathrm{~ns})$ & $.923(\mathrm{~ns})$ & $.949(\mathrm{~ns})$ & $.980(\mathrm{~ns})$ & $.993(\mathrm{~ns})$ & $1.006(\mathrm{~ns})$ & $.995(\mathrm{~ns})$ & $.997(\mathrm{~ns})$ & $.992(\mathrm{~ns})$ & $.991(\mathrm{~ns})$ & $.998(\mathrm{~ns})$ & $.995(\mathrm{~ns})$ \\
\hline Kka/mka/pygm & $1.498^{* *}$ & & $1.417^{* *}$ & $1.258(\mathrm{~ns})$ & $1.284(\mathrm{~ns})$ & $1.274(\mathrm{~ns})$ & $1.234(\mathrm{~ns})$ & $1.201(\mathrm{~ns})$ & $1.166(\mathrm{~ns})$ & $1.172(\mathrm{~ns})$ & $1.163(\mathrm{~ns})$ & 1.168(ns) & $1.148(\mathrm{~ns})$ & $1.145(\mathrm{~ns})$ \\
\hline \multicolumn{2}{|c|}{ Religion (ref = Catholic) } & & & $* * *$ & $* * *$ & $* * *$ & $* * *$ & $* * *$ & $* * *$ & $* * *$ & $* * *$ & $* * *$ & $* * *$ & $* * *$ \\
\hline Protestant & $1.399^{* * *}$ & & & $1.191^{* *}$ & $1.185^{* *}$ & $1.163^{* *}$ & $1.155^{* *}$ & $1.147^{* *}$ & $1.145^{*}$ & $1.149^{* *}$ & $1.147^{* *}$ & $1.145^{*}$ & $1.153^{* *}$ & $1.144^{*}$ \\
\hline Muslim & $.426^{* * *}$ & & & $.652^{* * *}$ & $.664^{* * *}$ & $.662^{* * *}$ & $.672^{* * *}$ & $.662^{* * *}$ & $.658^{* * *}$ & $.660^{* * *}$ & $.659^{* * *}$ & $.659^{* * *}$ & $.655^{* * *}$ & $.649^{* * *}$ \\
\hline Animist & $1.425^{* *}$ & & & $1.121(\mathrm{~ns})$ & $1.123(\mathrm{~ns})$ & $1.182(\mathrm{~ns})$ & $1.139(\mathrm{~ns})$ & $1.141(\mathrm{~ns})$ & $1.136(\mathrm{~ns})$ & 1.139 (ns) & 1.136(ns) & 1.150 (ns) & $1.202(\mathrm{~ns})$ & 1.196(ns) \\
\hline Other christian & $1.389 *$ & & & $1.090(\mathrm{~ns})$ & $1.062(\mathrm{~ns})$ & $1.059(\mathrm{~ns})$ & $1.079(\mathrm{~ns})$ & $1.099(\mathrm{~ns})$ & $1.073(\mathrm{~ns})$ & $1.078(\mathrm{~ns})$ & 1.073 (ns) & $1.071(\mathrm{~ns})$ & $1.068(\mathrm{~ns})$ & $1.054(\mathrm{~ns})$ \\
\hline No religion & $1.409^{*}$ & & & $.976(\mathrm{~ns})$ & $.999(\mathrm{~ns})$ & $1.017(\mathrm{~ns})$ & $1.013(\mathrm{~ns})$ & $.981(\mathrm{~ns})$ & $.974(\mathrm{~ns})$ & $.980(\mathrm{~ns})$ & $.979(\mathrm{~ns})$ & $.970(\mathrm{~ns})$ & $.975(\mathrm{~ns})$ & $.979(\mathrm{~ns})$ \\
\hline \multicolumn{2}{|c|}{ Household size $(\mathrm{ref}=6-10)$} & & & & $* *$ & $*$ & $*$ & * & $*$ & $*$ & $*$ & $*$ & {$[\mathrm{~ns}]$} & $*$ \\
\hline $1-5$ & $.916^{*}$ & & & & $1.086(\mathrm{~ns})$ & $1.087(\mathrm{~ns})$ & $1.075(\mathrm{~ns})$ & $1.082(\mathrm{~ns})$ & $1.009(\mathrm{~ns})$ & $1.018(\mathrm{~ns})$ & $.995(n s)$ & $.962(\mathrm{~ns})$ & $.962(\mathrm{~ns})$ & $.960(\mathrm{~ns})$ \\
\hline $11-15$ & $.754^{* * *}$ & & & & $.803^{* * *}$ & $.810^{* *}$ & $.819^{* *}$ & $.827^{* *}$ & $.843^{* *}$ & $.827^{* *}$ & $.830^{* *}$ & $.820^{* *}$ & $.814(\mathrm{~ns})$ & $.817^{* *}$ \\
\hline $16-20$ & $.666^{* * *}$ & & & & $.838(\mathrm{~ns})$ & $.852(\mathrm{~ns})$ & $.857(\mathrm{~ns})$ & $.880(\mathrm{~ns})$ & $.889(\mathrm{~ns})$ & $.865(\mathrm{~ns})$ & $.872(\mathrm{~ns})$ & $.787(\mathrm{~ns})$ & .775 (ns) & .769 (ns) \\
\hline $21-43$ & $.785(\mathrm{~ns})$ & & & & $.793(\mathrm{~ns})$ & $.820(\mathrm{~ns})$ & $.808(n s)$ & $.835(\mathrm{~ns})$ & $.862(\mathrm{~ns})$ & $.831(\mathrm{~ns})$ & $.837(\mathrm{~ns})$ & $.740(\mathrm{~ns})$ & $.728(\mathrm{~ns})$ & .727 (ns) \\
\hline
\end{tabular}




\section{Appendix 2. (Continuation)}

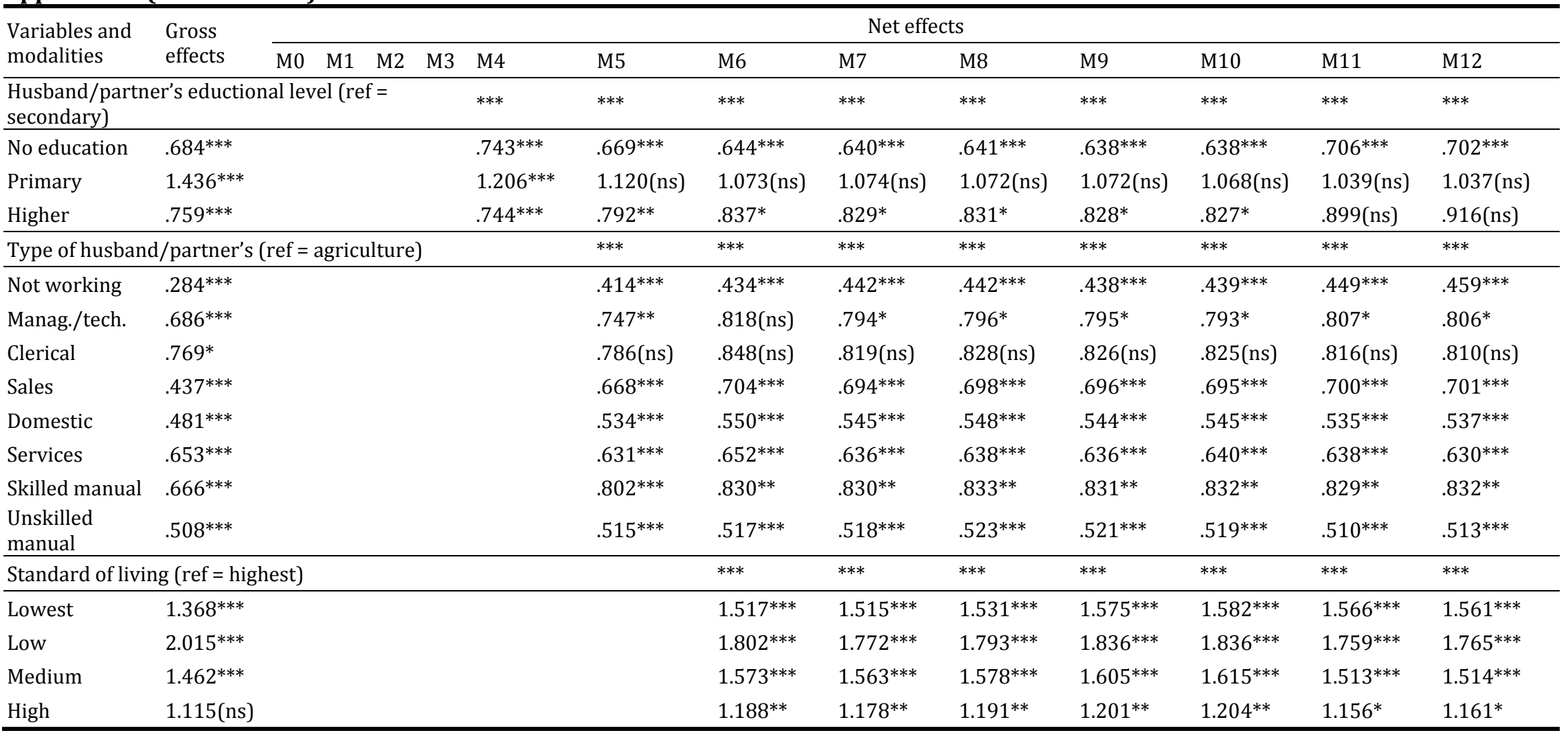




\section{Appendix 2. (Continuation)}

\begin{tabular}{|c|c|c|c|c|c|c|c|c|c|c|c|c|c|c|}
\hline \multirow{2}{*}{$\begin{array}{l}\text { Variables and } \\
\text { modalities }\end{array}$} & \multirow{2}{*}{$\begin{array}{l}\text { Gross } \\
\text { effects }\end{array}$} & \multicolumn{13}{|c|}{ Net effects } \\
\hline & & M0 & M1 & M2 & M3 & M4 & M5 & M6 & M7 & M8 & M9 & M10 & M11 & M12 \\
\hline \multicolumn{9}{|c|}{ Relationship with the household head (ref = wife) } & $* * *$ & $* * *$ & $* * *$ & $* * *$ & $* * *$ & $* * *$ \\
\hline Head & \multicolumn{8}{|l|}{$1.999^{* * *}$} & $1.489^{* * *}$ & $1.908^{* * *}$ & $1.886^{* * *}$ & $1.873^{* * *}$ & $1.873^{* * *}$ & $1.710^{* * *}$ \\
\hline Daughter & \multicolumn{8}{|l|}{$.599 * * *$} & $.936(\mathrm{~ns})$ & $1.047(\mathrm{~ns})$ & $1.010(\mathrm{~ns})$ & $1.003(\mathrm{~ns})$ & $1.001(\mathrm{~ns})$ & $.877(\mathrm{~ns})$ \\
\hline Daughter-in-law & \multicolumn{8}{|l|}{$.753^{* *}$} & $.850(\mathrm{~ns})$ & $.949(\mathrm{~ns})$ & $.924(\mathrm{~ns})$ & $.919(\mathrm{~ns})$ & $.911(\mathrm{~ns})$ & $.891(\mathrm{~ns})$ \\
\hline Granddaughter & \multicolumn{8}{|l|}{$.584^{*}$} & $.992(\mathrm{~ns})$ & $1.100(\mathrm{~ns})$ & $1.054(\mathrm{~ns})$ & $1.068(\mathrm{~ns})$ & $1.099(\mathrm{~ns})$ & $.950(\mathrm{~ns})$ \\
\hline Mot/m-i-l/str & \multicolumn{8}{|l|}{$1.287(\mathrm{~ns})$} & $1.268(\mathrm{~ns})$ & $1.383^{*}$ & $1.343(\mathrm{~ns})$ & $1.344(\mathrm{~ns})$ & $1.328(\mathrm{~ns})$ & 1.131(ns) \\
\hline $\begin{array}{l}\text { Other } \\
\text { relationship }\end{array}$ & \multicolumn{8}{|l|}{$.791^{*}$} & $1.223(\mathrm{~ns})$ & $1.314^{*}$ & $1.275(\mathrm{~ns})$ & $1.271(\mathrm{~ns})$ & $1.256(\mathrm{~ns})$ & $1.175(\mathrm{~ns})$ \\
\hline $\begin{array}{l}\text { Adoptive } \\
\text { daughter }\end{array}$ & \multicolumn{8}{|l|}{$.332^{* * *}$} & $.513(\mathrm{~ns})$ & $.570(\mathrm{~ns})$ & $.554(\mathrm{~ns})$ & $.546(\mathrm{~ns})$ & $.548(\mathrm{~ns})$ & $.505(\mathrm{~ns})$ \\
\hline Not related & \multicolumn{8}{|l|}{$1.274(\mathrm{~ns})$} & $1.600^{*}$ & $1.847^{* *}$ & $1.777^{* *}$ & $1.786^{* *}$ & $1.789^{* *}$ & $1.665^{*}$ \\
\hline Niece & \multicolumn{8}{|l|}{$.358^{* * *}$} & $.620^{*}$ & $.753(\mathrm{~ns})$ & $.720^{*}$ & $.720^{*}$ & $.732(\mathrm{~ns})$ & $.653^{* *}$ \\
\hline \multicolumn{10}{|c|}{ Sex of household head (ref = male) } & $* *$ & $* *$ & $* *$ & ** & $*$ \\
\hline Female & \multicolumn{9}{|l|}{ 1. $286^{* * *}$} & $.773^{* *}$ & $.775^{* *}$ & $.780^{* *}$ & $.790^{* *}$ & $.800^{*}$ \\
\hline \multicolumn{11}{|c|}{ Number of births of the 5 years preceding the survey (ref = none) } & (ns) & (ns) & (ns) & (ns) \\
\hline 1 birth & \multicolumn{10}{|l|}{$.752^{* * *}$} & $.946(\mathrm{~ns})$ & $.992(\mathrm{~ns})$ & $.994(\mathrm{~ns})$ & $.997(\mathrm{~ns})$ \\
\hline 2 births & \multicolumn{10}{|l|}{$.728^{* * *}$} & $.887(\mathrm{~ns})$ & $.943(\mathrm{~ns})$ & $.940(\mathrm{~ns})$ & $.946(\mathrm{~ns})$ \\
\hline 3-6 births & \multicolumn{10}{|l|}{$.674^{* * *}$} & $.834(\mathrm{~ns})$ & $.888(n s)$ & $.878(\mathrm{~ns})$ & $.882(\mathrm{~ns})$ \\
\hline
\end{tabular}




\begin{tabular}{|c|c|c|c|c|c|c|c|c|c|c|c|c|c|c|}
\hline \multirow{2}{*}{$\begin{array}{l}\text { Variables and } \\
\text { modalities }\end{array}$} & \multirow{2}{*}{$\begin{array}{l}\text { Gross } \\
\text { effects }\end{array}$} & \multicolumn{13}{|c|}{ Net effects } \\
\hline & & M0 & M1 & M2 & M3 & M4 & M5 & M6 & M7 & M8 & M9 & M10 & M11 & M12 \\
\hline \multicolumn{12}{|c|}{ Number of children under 5 years old (de jure) $[$ ref $=0(<5$ years old $)]$} & (ns) & (ns) & (ns) \\
\hline $\begin{array}{l}1(<5 \text { years } \\
\text { old })\end{array}$ & $.863^{* *}$ & & & & & & & & & & & $1.005(\mathrm{~ns})$ & $1.008(\mathrm{~ns})$ & $1.012(\mathrm{~ns})$ \\
\hline $\begin{array}{l}2(<5 \text { years } \\
\text { old })\end{array}$ & $.762^{* * *}$ & & & & & & & & & & & $.885(\mathrm{~ns})$ & $.888(\mathrm{~ns})$ & $.893(\mathrm{~ns})$ \\
\hline $\begin{array}{l}3(<5 \text { years } \\
\text { old })\end{array}$ & $.617^{* * *}$ & & & & & & & & & & & $.844(\mathrm{~ns})$ & $.849(\mathrm{~ns})$ & $.857(\mathrm{~ns})$ \\
\hline $\begin{array}{l}4(<5 \text { years } \\
\text { old })\end{array}$ & $.720^{* * *}$ & & & & & & & & & & & $1.027(\mathrm{~ns})$ & $1.027(\mathrm{~ns})$ & $1.037(\mathrm{~ns})$ \\
\hline $\begin{array}{l}5-19(<5 \text { years } \\
\text { old })\end{array}$ & $.699^{* * *}$ & & & & & & & & & & & $1.131(\mathrm{~ns})$ & $1.134(\mathrm{~ns})$ & $1.152(\mathrm{~ns})$ \\
\hline \multicolumn{13}{|c|}{ Educational level (ref = secondary) } & $* * *$ & $* * *$ \\
\hline No education & $.807^{* * *}$ & & & & & & & & & & & & $.882(\mathrm{~ns})$ & $.882(\mathrm{~ns})$ \\
\hline Primary & $1.737^{* * *}$ & & & & & & & & & & & & $1.317^{* * *}$ & 1. $306^{* * *}$ \\
\hline Higher & $.867(\mathrm{~ns})$ & & & & & & & & & & & & $.838(n s)$ & $.836(n s)$ \\
\hline Widowed & $2.508^{* * *}$ & & & & & & & & & & & & & $1.049(\mathrm{~ns})$ \\
\hline Divorced/sep. & $1.359 * * *$ & & & & & & & & & & & & & $1.469^{* * *}$ \\
\hline \multicolumn{2}{|c|}{ Ages group (ref = 15-19) } & $* * *$ & $* * *$ & $* * *$ & $* * *$ & $* * *$ & $* * *$ & $* * *$ & $* * *$ & $* * *$ & $* * *$ & $* * *$ & $* * *$ & $* * *$ \\
\hline $20-24$ & $1.794^{* * *}$ & $1.919^{* * *}$ & $1.807^{* * *}$ & $1.780^{* * *}$ & $1.756^{* * *}$ & $1.789^{* * *}$ & $1.757^{* * *}$ & $1.771^{* * *}$ & $1.754^{* * *}$ & $1.766^{* * *}$ & $1.820^{* * *}$ & $1.818^{* * *}$ & $1.825^{* * *}$ & $1.801^{* * *}$ \\
\hline $25-29$ & $3.092^{* * *}$ & $3.372^{* * *}$ & $3.041^{* * *}$ & $2.997^{* * *}$ & $2.979^{* * *}$ & $3.086^{* * *}$ & $2.971^{* * *}$ & $3.018^{* * *}$ & $2.904^{* * *}$ & $2.938^{* * *}$ & $3.038^{* * *}$ & $3.053^{* * *}$ & $3.104^{* * *}$ & $3.049^{* * *}$ \\
\hline $30-34$ & $4.604^{* * *}$ & $5.042^{* * *}$ & $4.513^{* * *}$ & $4.419^{* * *}$ & $4.454^{* * *}$ & $4.690^{* * *}$ & $4.487^{* * *}$ & $4.617^{* * *}$ & $4.342^{* * *}$ & $4.409^{* * *}$ & $4.506^{* * *}$ & $4.513^{* * *}$ & $4.523^{* * *}$ & $4.418^{* * *}$ \\
\hline $35-39$ & $5.822^{* * *}$ & $6.409^{* * *}$ & $5.931^{* * *}$ & $5.730^{* * *}$ & $5.844^{* * *}$ & $6.167^{* * *}$ & $5.982^{* * *}$ & $6.087^{* * *}$ & $5.586^{* * *}$ & $5.669^{* * *}$ & $5.645^{* * *}$ & $5.597^{* * *}$ & $5.613^{* * *}$ & $5.492^{* * *}$ \\
\hline $40-44$ & $6.507^{* * *}$ & $7.014^{* * *}$ & $6.558^{* * *}$ & $6.390^{* * *}$ & $6.522^{* * *}$ & $6.933^{* * *}$ & $6.824^{* * *}$ & $6.987^{* * *}$ & $6.285^{* * *}$ & $6.391^{* * *}$ & $6.253^{* * *}$ & $6.210^{* * *}$ & $6.316^{* * *}$ & $6.189^{* * *}$ \\
\hline $45-49$ & $8.248^{* * *}$ & $8.959^{* * *}$ & $7.633^{* * *}$ & $7.398^{* * *}$ & $7.515^{* * *}$ & $7.995^{* * *}$ & $7.751^{* * *}$ & $7.862^{* * *}$ & $6.972^{* * *}$ & $7.081^{* * *}$ & $6.821^{* * *}$ & $6.827^{* * *}$ & $6.859^{* * *}$ & $6.722^{* * *}$ \\
\hline Prob > chi2 & & .000 & .000 & .000 & .000 & .000 & .000 & .000 & .000 & .000 & .000 & .000 & .000 & .000 \\
\hline
\end{tabular}

Note: $\left({ }^{* *}\right)=1 \% ;\left({ }^{* *}\right)=5 \% ;\left({ }^{*}\right)=10 \%$; ns = not significant. 


\section{Note}

1. Proportion of labor force participation in working-age population (15-59 years old).

\section{References}

Aly, Y. H. and I. A. Quisi. 1996. "Determinants of Women Labor Force Participation in Kuwait: A Logit Analysis." The Middle East Business and Economic Review 8(2):1-9.

Aminu, A. 2010. "Determinants of Participation and Earnings in Wage Employment in Nigeria." Presented at 5th IZA/World Bank Conference on Employment and Development, May 3-4, Cape Town, South Africa.

Angrist, J. 2001. "How Do Sex Ratios Affect Marriage and Labor Markets? Evidence From America's Second Generation.” IZA DP No. 368. Retrieved (http://ftp.iza. org/dp368.pdf).

Aromolaran, A. 2004. "Female Schooling, Non-market Productivity, and Labor Market Participation in Nigeria." Yale University Economic Growth Center Discussion Paper No. 879. Retrieved (http://www.econ.yale.edu/growth_pdf/ cdp879.pdf).

Azid, T., M. Aslam, and M. O. Chaudary. 2001. "Poverty, Female Labor Force Participation, and Cottage Industry: A Case Study of Cloth Embroidery in Rural Multan." The Pakistan Development Review 40(4):1105-1118.

Becker, G. S. 1981. A Treatise on the Family. Cambridge, MA: Harvard University Press.

-1993. Human Capital: A Theoretical and Empirical Analysis. 3rd ed. Chicago, USA: University of Chicago Press.

Benefo, K. D. and V. K. Pillai. 2003. "Determinants of Women Non-family Work in Ghana and Zimbabwe." Canadian Studies in Population 30(2):389-406.

Caputo, R. 1997. "Population, Labor Force and Employment: A Prospective Analysis." Pp. 1-40 in Prospective Studies. Santiago: Ministry of Planning.

Chamlou, N., S. Muzi, and H. Ahmed. 2011. "Understanding the Determinants of Female Labor Force Participation in the Middle East and North Africa Region: The Role of Education and Social Norms in Amman." AlmaLaurea Working Papers. Retrieved (https://www.academia. edu/6345264/Understanding_the_Determinants_of_Female _Labor_Force_Participation_in_the_Middle_East_and_Nor th_Africa_Region_The_Role_of_Education_and_Social_N orms_in_Amman).

Chaudhry, I. S. and F. Nosheen. 2009. "The Determinants of Women Empowerment in Southern Punjab (Pakistan): An Empirical Analysis." European Journal of Social Sciences 10(2):216-229.
Contreras, D. and G. Plaza. 2010. "Cultural Factors in Women's Labor Force Participation in Chile." Feminist Economics 16(2):27-46.

Contreras, D., E. Puentes, and D. Bravo. 2005. "Female Labor Force Participation in Greater Santiago, Chile: 1957-1997. A Synthetic Cohort Analysis." Journal of International Development 17(2):169-186.

Desvaux, G., S. Devillard, and P. Baumgarten. 2007. "Women Matter: La Mixité Levier de Performance de L'entreprise" (Women Matter: Gender Diversity, a Corporate Performance Driver). Paris, France: McKinsey \& Company. Retrieved (http://www.mckinsey.com/locations/paris/home/ womenmatter/pdfs/Women_matter_oct2007_english.pdf).

Dussault, G. 1987. À Travail Equivalent, Salaire Egal: La Portée de la Revendication (With Equivalent Work, Equal Wages: The Range of the Claim). Montreal: Institution of Work-Applied Research.

Fadayomi, T. O. and I. O. Ogunrinola. 2014. "Determinants of Labour Force Participation in Nigeria: The Influence of Household Structure." Journal of Economics and Development Studies 2(2):169-190.

Faridi, M. Z., I. S. Chaudhry, and M. Anwar. 2009. "The Socio-Economic and Demographic Determinants of Women Work Participation in Pakistan: Evidence From Bahawalpur District." A Research Journal of South Asian Studies 24(2):351-367.

Farre, L. and F. Vella. 2007. "The Intergenerational Transmission of Gender Role Attitudes and Its Implications for Female Labor Force Participation." IZA DP No. 2802. Retrieved (https://www.researchgate.net/publication/ 5134620_The_Intergenerational_Transmission_of_Gender Role_Attitudes_and_Its_Implications_for_Female_Labor_F orce_Participation).

Fernandez, R., A. Fogli, and C. Olivetti. 2004. "Mothers and Sons Formation and Female Labor Force Dynamics." Quarterly Journal of Economics 119(4):1249-1299.

Fraser, N. 1990. "What's Critical About Critical Theory? The Case of Habermas and Gender." Pp. 49-88 in Feminist Theory and Critical Theory. Essays on Gender Policy in Late Capitalist Societies, edited by S. Benhabib and D. Cornell. Valencia, Spain: Alfons El Magnanim.

Galor, O. and D. N. Weil. 1996. "The Gender Gap, Fertility and Growth." American Economic Review 86(3):374-387.

Garcia, P. 1995. "Employment and Participation in Chile." Coleccion de Estudios Cieplan (Collection of Cieplan Studies) 41:7-40.

Hafeez, A. and E. Ahmad. 2002. "Factors Determining the Labor Force Participation Decision of Educated Married Women in a District of Punjab." Pakistan Economic and Social Review 11(1):75-88.

Hartman, H. 1976. "Capitalism, Patriarchy, and Job 
Segregation by Sex." In Women and Workplace, edited by M. Blaxal and B. Reagan. Chicago, IL: University of Chicago Press.

Klasen, S. 1999. "Does Gender Inequality Reduce Growth and Development?" Policy Research Report on Gender and Development Working Paper Series, No. 7. Retrieved (http://siteresources.worldbank.org/INTGENDER/Resource s/wp7.pdf).

Kozel, V. and H. Alderman. 1990. "Factors Determining Work Participation and Labor Supply Decisions in Pakistan's Urban Area." The Pakistan Development Review 29(1):1-18.

Letablier, M. T., A. Luci, A. Math, and O. Thévenon. 2009. "The Costs of Raising Children and the Effectiveness of Policies to Support Parenthood in European Countries: A Literature Review." INED Working Paper 158. Retrieved (http://europa.eu/epic/docs/eu_report_cost_of_children_fina 1_11-05-2009.pdf).

Locoh, T., A. Labourie-Racape, and C. Tichit. 1996. Genre et développement: Des pistes à suivre (Gender and Development: Orientations to Be Considered). Paris: CEPED.

Longwe, A., J. Smits, and E. Jong. 2013. "Number and Spacing of Children and Women's Employment in Africa." NICE Working Paper 13(103):1-23.

Lopez-Claros, A. and S. Zahidi. 2005. "Women's Empowerment: Measuring the Global Gender Gap." World Economic Forum. Retrieved (http://www.unece. org/fileadmin/DAM/stats/gender/publications/Multi-Countr y/WomenEmpowerment.pdf).

Mincer, J. 1962. "Labor Force Participation of Married Women: A Study of Labor Supply.” Pp. 63-97 in Aspects of Labor Economics, edited by H. G. Lowis. Princeton, NJ: Princeton University Press.

- 1974. Schooling, Experience and Earnings. New York: National Bureau of Economic Research.

Naqvi, Z. F. and L. Shahnaz. 2002. "How Do Women Decide to Work in Pakistan?" The Pakistan Development Review 41(4):495-513.

Ntuli, M. and M. Wittenberg. 2013. "Determinants of Black Women's Labour Force Participation in Post-apartheid South Africa." Journal of African Economies 22(3):347-374.

Pissarides, C. 2006. "Lisbon Five Years Later: What Future for
European Employment and Growth?" Keynote address delivered at the Austrian Presidency Conference on Innovations in Labor Market Policies: Challenges in Times of Globalisation.

Sackey, H. A. 2005. "Female Labour Force Participation in Ghana: The Effects of Education." AERC Research Paper 150. Retrieved (https://www.researchgate.net/publication/ 254850610_Female_labour_force_participation_in_Ghana_ The_effects_of_education).

Sacks, K. 1979. Sisters and Wives. Westport, CT: Greenwood. Seguino, S. 2007. "Evidence on Global Trends in Gender Norms and Stereotypes." Feminist Economics 13(2):1-28.

Shaheen, S., H. S. Maqbool, and S. A. Masood. 2011. "Female Labor Force Participation in Pakistan: A Case of Punjab." Journal of Social Development Sciences 2(3):104-110.

United Nations. 1984. Manuel X: Techniques Indirectes D'estimation Démographique (Handbook X: Indirect Techniques of Population Estimate). New York: United Nations.

World Bank. 2012. World Development Indicators. Retrieved (http://data.worldbank.org/country/cameroon\#cp_wdi).

\section{Bios}

Henri Bello Fika, Ph.D. candidate in Economic Analysis at the Postgraduate Training School of Economics and Management of the University of Dschang, Cameroon; demographer/population analyst, Institute of Demographic Training and Research (IFORD); Ministry of Economy, Planning and Regional Development, Cameroon; research fields: population projections, gender and development, population, environment and economic growth, demographic dividend, monetary policy, applied econometrics, economic modelling, population and health, human capital, labor market opportunities and economic development, family's structural dynamics.

Germain Dzoyem Sokeng, postgraduate in Economic Analysis, demographer/population analyst, Institute of Demographic Training and Research (IFORD); Ministry of Economy, Planning and Regional Development, Cameroon; research fields: population and health, population projections, demographic dividend, monetary policy, applied econometrics, population, environment and economic growth. 